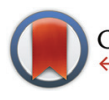

CrossMark \&lick for updates

Cite this: Dalton Trans., 2015, 44 16325

Received 25th July 2015,

Accepted 15th August 2015

DOI: $10.1039 / c 5 d t 02851 \mathrm{e}$

www.rsc.org/dalton

\title{
Preparation of enantiomerically pure open calcocene and strontocene complexes and their application in ring opening polymerizations of rac-lactide $\uparrow$
}

\author{
Ann Christin Fecker, ${ }^{\mathrm{a}}$ Matthias Freytag, ${ }^{\mathrm{a}}$ Peter G. Jones, ${ }^{\mathrm{a}}$ Ning Zhao, ${ }^{\mathrm{b}}$ Guofu Zi*b and \\ Marc D. Walter*a
}

\begin{abstract}
The synthesis of $C_{2}$ symmetric enantiomerically pure open $\mathrm{Ca}$ and $\mathrm{Sr}$ metallocenes, $\left[\left(\eta^{5}-\mathrm{pdl}\right)_{2} \mathrm{Ca}(\mathrm{thf})\right](\mathbf{1})$ and $\left[\left(\eta^{5}-p d l^{*}\right)_{2} S r(\text { thf })_{2}\right]$ (2) (pdl* = dimethylnopadienyl) is described and these complexes were fully characterized. The solid state structures confirm that the pd** ligands coordinate exclusively with the less sterically demanding site to the $\mathrm{Ca}$ and $\mathrm{Sr}$ atoms. These complexes are active catalysts for the controlled ring opening polymerization (ROP) of rac-lactide to give heterotactically enriched polylactides (PL) with narrow polydispersities (PDI $=1.29-1.31$ ) and without adding further activators.
\end{abstract}

\section{Introduction}

Since the discovery of ferrocene, $\mathrm{Cp}_{2} \mathrm{Fe}$, organometallic chemistry has been dominated by the cyclopentadienyl (Cp) ligand; a large number of cyclopentadienyl complexes with tailored steric and electronic properties have been developed ${ }^{1-5}$ for various applications ranging from material science and small molecule activation to (enantioselective) catalysis. In contrast, the chemistry of the "open" analogues, the pentadienyl (pdl) ligands, and their corresponding metal complexes has received significantly less attention and the investigations have mainly focused on d-transition metals, ${ }^{6-10}$ whereas complexes of the rare earth, ${ }^{11-21}$ actinide ${ }^{21-25}$ and main group metals ${ }^{26-38}$ have been surprisingly scarce. The diverging developments of these ligand types is surprising, considering that $\mathrm{Cp}$ and pdl ligands are indeed related, but pdl derivatives can also adopt different hapticities (Chart 1) and exhibit in its $\eta^{5}$-U coordination better $\pi$-donor and $\delta$-acceptor capabilities, which allow the stabilization of low oxidation states such as $\mathrm{Hf}(\mathrm{II})$ and $\mathrm{Zr}(\mathrm{II}) .{ }^{6-10}$

There are only scattered reports of pdl complexes acting as catalysts in polymerization processes. ${ }^{12,20,39}$ Inspired by these observations, we recently initiated a research program on sterically demanding and chiral pentadienyl ligands and their

\footnotetext{
${ }^{a}$ Institut für Anorganische und Analytische Chemie, Technische Universität, Braunschweig, Hagenring 30, 38106 Braunschweig, Germany.

E-mail: mwalter@tu-bs.de

${ }^{b}$ Department of Chemistry, Beijing Normal University, Beijing 100875, China. E-mail: gzi@bnu.edu.cn

$\dagger$ CCDC 1415170 and 1415171. For crystallographic data in CIF or other electronic format see DOI: 10.1039/c5dt02851e
}
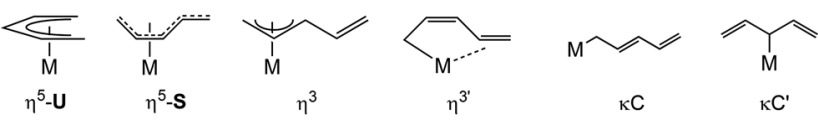

Chart 1 Different hapticity modes associated with pdl ligands.

coordination chemistry. ${ }^{35-38,40}$ In the course of these investigations we also set out to close currently existing gaps in the periodic table, to prepare pentadienyl complexes of metals such as the heavier alkaline earths, $(\mathrm{Ca}, \mathrm{Sr} \text { and } \mathrm{Ba})^{37}$ that are currently less well explored, and to establish new reactivity patterns.

In this contribution the synthesis of the first chiral open metallocenes of $\mathrm{Ca}$ and $\mathrm{Sr}$ derived from the natural product $(1 R)-(-)$ myrtenal is reported, together with their application in the ring-opening polymerization (ROP) of rac-lactide. Ca complexes have become interesting catalysts for various catalytic applications including polymerizations of olefins (styrene) and polar monomers such as lactones and lactides. ${ }^{41}$ Lactides are interesting renewable precursors for biodegradable and biocompatible polymers and the resulting polylactides show interesting physical and mechanical properties. ${ }^{42-46}$ While enantiomerically pure polylactide melts at $180^{\circ} \mathrm{C}$, stereocomplex derivatives formed by an equivalent mixture of poly(L-lactide) and poly(D-lactide) melt at $230{ }^{\circ} \mathrm{C} .{ }^{47,48}$ Furthermore the rate of degradation can be modulated by the chain stereochemistry. ${ }^{4-51}$ Several catalyst systems for the ROP of cyclic esters, based on magnesium, zinc, calcium, aluminum, lanthanides, tin, group 4 metals, germanium, indium and iron, have been reported. ${ }^{42,44-46,52-58}$ 


\section{Results and discussion}

\section{Complex synthesis and characterization}

Potassium dimethylnopadienide, $\mathrm{K}\left(\mathrm{pdl}{ }^{*}\right)$ (2 equiv.), reacts cleanly with $\mathrm{MI}_{2}(\mathrm{M}=\mathrm{Ca}$ and $\mathrm{Sr})$ in THF to give the respective open metallocenes, $\left[\left(\eta^{5}-\text { pdl }\right)_{2} \mathrm{Ca}(\right.$ thf $\left.)\right]$ (1) and $\left[\left(\eta^{5}-\text { pdl }{ }^{*}\right)_{2} \mathrm{Sr}-\right.$ (thf $)_{2}$ ] (2). These complexes are very air- and moisture-sensitive, but can be isolated after crystallization in moderate yields. They are readily soluble in aromatic and aliphatic hydrocarbons and THF.

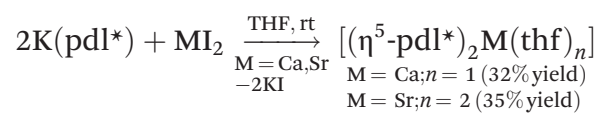

Various spectroscopic techniques, elemental analyses and X-ray diffraction were employed for the characterization of these compounds (see Experimental section for details). In solution the open metallocenes 1 and 2 adopt a $C_{2}$ symmetric structure, in which the pentadienyl ligands display an $\eta^{5}-\mathrm{U}$ conformation. NOESY spectroscopy shows a strong NOE between the $\mathrm{H}$ atoms H1-endo and H5 (Chart 2 and Fig. 1).

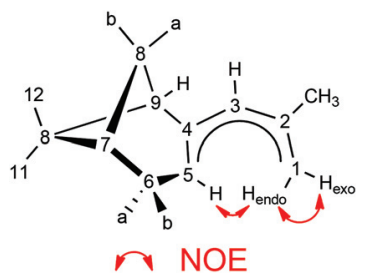

Chart 2

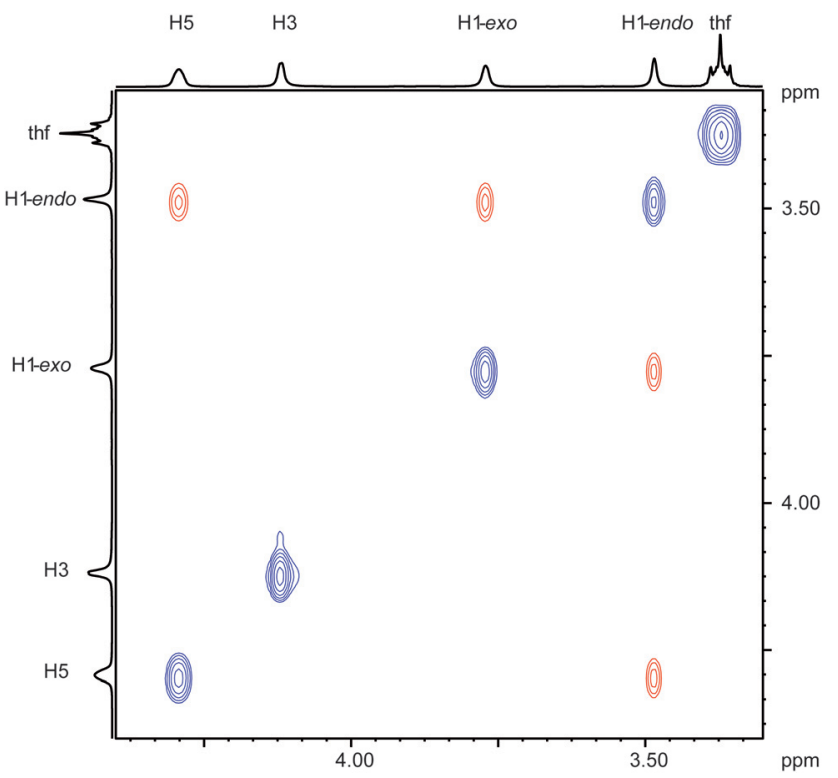

Fig. $1{ }^{1} \mathrm{H}-{ }^{1} \mathrm{H}$ NOESY NMR spectrum of the pentadienyl moiety in complex 1 recorded in $\mathrm{C}_{6} \mathrm{D}_{6}$ at ambient temperature.
Table 1 Crystallographic data

\begin{tabular}{lll}
\hline Compound reference & $\mathbf{1}$ & $2 \cdot($ thf $)$ \\
Chemical formula & $\mathrm{C}_{30} \mathrm{H}_{46} \mathrm{CaO}$ & $\mathrm{C}_{38} \mathrm{H}_{62} \mathrm{O}_{3} \mathrm{Sr}$ \\
Formula mass & 462.75 & 654.50 \\
Crystal system & Orthorhombic & Trigonal \\
$a / \AA$ & $13.5295(3)$ & $14.1418(5)$ \\
$b / \AA$ & $13.7062(3)$ & $14.1418(5)$ \\
$c / \AA$ & $15.0026(3)$ & $15.6028(5)$ \\
$\alpha /{ }^{\circ}$ & 90.00 & 90.00 \\
$\beta /{ }^{\circ}$ & 90.00 & 90.00 \\
$\gamma /{ }^{\circ}$ & 90.00 & 120.00 \\
Unit cell volume $/ \AA^{3}$ & $2782.07(10)$ & $2702.37(16)$ \\
Temperature/K & $100(2)$ & $100(2)$ \\
Space group & $P 2_{1} 2_{1} 2_{1}$ & $P 3_{1} 21$ \\
No. of formula units per unit cell, $Z$ & 4 & 3 \\
Radiation type & $\mathrm{Mo} \mathrm{K \alpha}$ & $\mathrm{Mo} \mathrm{K \alpha}$ \\
Absorption coefficient, $\mu / \mathrm{mm}^{-1}$ & 0.244 & 1.529 \\
No. of reflections measured & 119013 & 67826 \\
No. of independent reflections & 5682 & 3696 \\
$R_{\text {int }}$ & 0.0554 & 0.0657 \\
Final $R_{1}$ values $(I>2 \sigma(I))$ & 0.0336 & 0.0403 \\
Final w $R\left(F^{2}\right)$ values $(I>2 \sigma(I))$ & 0.0811 & 0.0894 \\
Final $R_{1}$ values $($ all data $)$ & 0.0371 & 0.0453 \\
Final w $R\left(F^{2}\right)$ values $($ all data) & 0.0831 & 0.0919 \\
Goodness of fit on $F^{2}$ & 1.050 & 1.052 \\
Flack parameter & $0.01(3)$ & $-0.005(10)$ \\
CCDC & 1415170 & 1415171 \\
& &
\end{tabular}

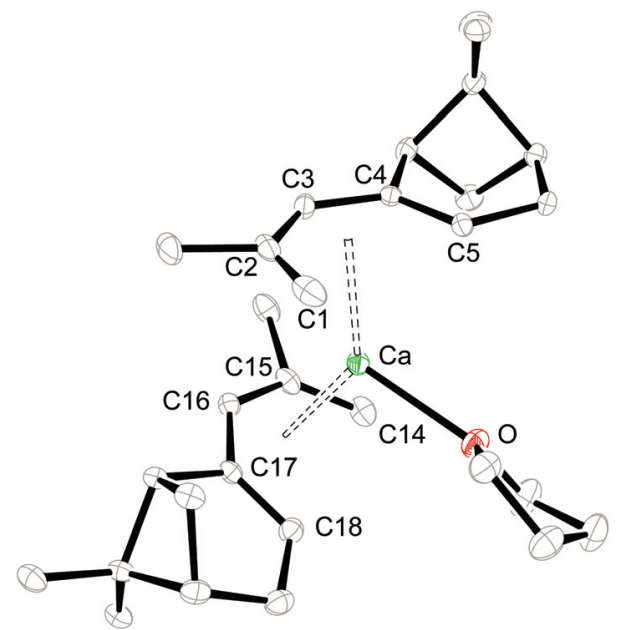

Fig. 2 ORTEP of 1 with thermal displacement parameters drawn at 30\% probability. Hydrogen atoms were omitted for clarity.

Single crystals of 1 and $\mathbf{2}$ were grown from THF/hexane mixtures at $-30{ }^{\circ} \mathrm{C}$ (Table 1) and their molecular structures are shown in Fig. 2 and 3. Attempts to crystallize these compounds from pure hexane solutions only lead to amorphous precipitates, but on addition of even small amounts of THF, crystallization is readily induced. Complex $\mathbf{1}$ crystallizes in the orthorhombic space group $P 2{ }_{1} 2_{1} 2_{1}$, whereas 2 crystallizes in the trigonal space group $P 3_{1} 21$ with one uncoordinated THF molecule in the crystal lattice. Selected bond distances and angles can be found in Table 2 . 


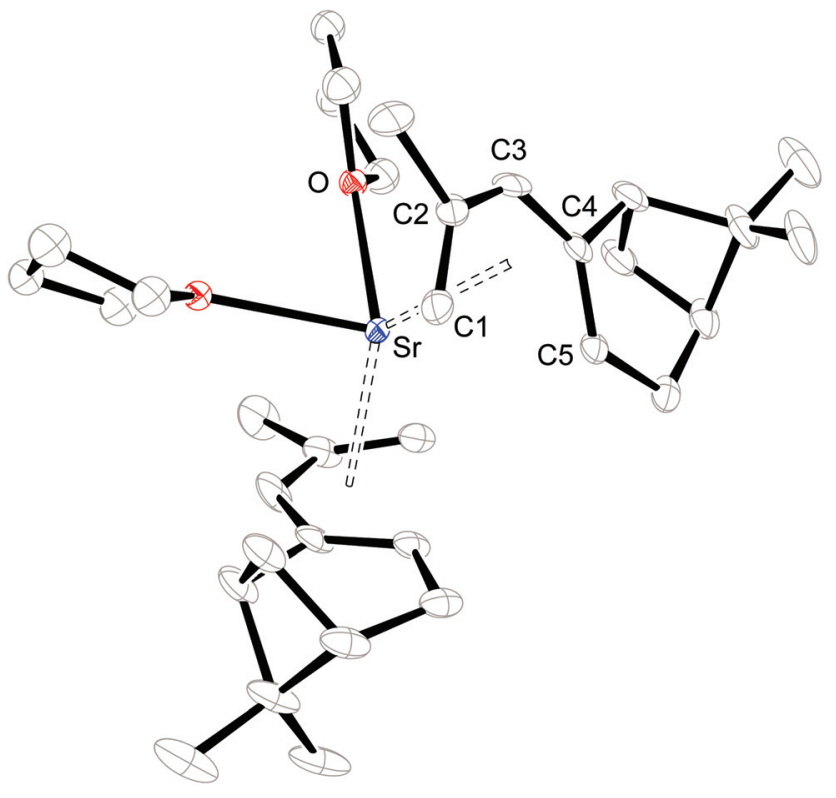

Fig. 3 ORTEP of 2 with thermal displacement parameters drawn at $30 \%$ probability. Hydrogen atoms were omitted for clarity. The coordinated THF is disordered over two positions, but only one of these is shown.

Table 2 Selected bond distances $(\AA ̊)$ and angles $\left(^{\circ}\right)$

\begin{tabular}{|c|c|c|}
\hline Compound & 1 & 2 \\
\hline $\mathrm{C} 1 / \mathrm{C} 14-\mathrm{C} 2 / \mathrm{C} 15$ & $1.360(3) ; 1.375(3)$ & $1.369(6)$ \\
\hline C2/C15-C3/C16 & $1.428(3) ; 1.421(3)$ & $1.417(6)$ \\
\hline $\mathrm{C} 3 / \mathrm{C} 16-\mathrm{C} 4 / \mathrm{C} 17$ & $1.431(2) ; 1.439(2)$ & $1.440(5)$ \\
\hline C4/C17-C5/C18 & $1.372(2) ; 1.371(3)$ & $1.366(5)$ \\
\hline $\mathrm{C} 1 / \mathrm{C} 14 \cdots \mathrm{C} 5 / \mathrm{C} 18$ & $3.205 ; 3.235$ & 3.246 \\
\hline $\mathrm{M}-\mathrm{C} 1 / \mathrm{C} 14$ & $2.728(2) ; 2.713(2)$ & $2.918(4)$ \\
\hline $\mathrm{M}-\mathrm{C} 2 / \mathrm{C} 15$ & $2.6896(18) ; 2.6531(18)$ & $2.904(4)$ \\
\hline M-C3/C16 & $2.6577(19) ; 2.6217(18)$ & $2.862(4)$ \\
\hline M-C4/C17 & $2.7426(16) ; 2.7422(17)$ & $2.942(3)$ \\
\hline M-C5/C18 & $2.8009(18) ; 2.9181(19)$ & $2.958(3)$ \\
\hline M-C (Å, range $)$ & $2.9181(19)-2.6217(18)$ & $2.958(3)-2.862(4)$ \\
\hline $\mathrm{M}-\mathrm{C}(\AA$, average $)$ & $2.727 \pm 0.085$ & $2.917 \pm 0.037$ \\
\hline M-pdl plane & $2.261 ; 2.265$ & 2.426 \\
\hline $\begin{array}{l}\text { M-pdl } \\
\text { (A, averagroid }{ }^{a}\end{array}$ & 2.222 & 2.485 \\
\hline $\mathrm{M}-\mathrm{O}(\AA)$ & $2.3400(13)$ & $2.528(4), 2.604(5)^{b}$ \\
\hline $\begin{array}{l}\mathrm{pdl}_{\text {centroid }}^{*} \\
\mathrm{M}^{*} \text { pdl }_{\text {centroid }}^{*}(\mathrm{o})\end{array}$ & 135.6 & 133.3 \\
\hline$\alpha^{c}$ & 25.3 & 67.9 \\
\hline$\chi^{d}$ & 28.4 & 50.0 \\
\hline
\end{tabular}

${ }^{a} \mathrm{pdl}_{\text {centroid }}$ is the centroid of the pentadienyl ligand. ${ }^{b}$ The coordinate THF ligand is disordered over two positions. ${ }^{c} \alpha$ is defined as the angle formed by the two dienyl planes. ${ }^{d}$ Conformational angle of the pdl* with respect to each other (as defined in Chart 3).

Consistent with the solution studies, the pdl* ligands in $\mathbf{1}$ and 2 also adopt an $\eta^{5}$-U conformation in the solid state; and, as in previous studies on open metallocenes of the transition metals, the pdl* systems coordinate site-selectively with the less sterically demanding face (syn to the $\mathrm{CH}_{2}$-bridge of the bicyclic ligand framework) directed toward the metal atom.

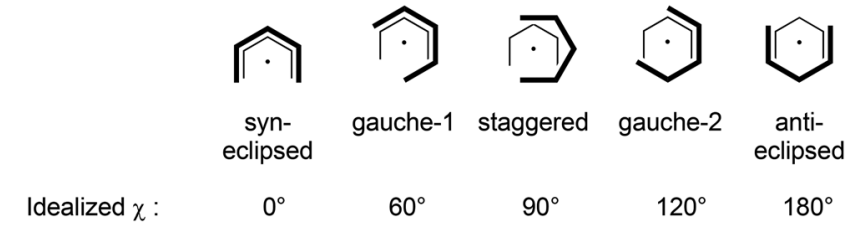

Chart 3 Conformational of two pentadienyl ligands.

Complex 1 shows approximate (non-crystallographic) $C_{2}$ symmetry, in which the $C_{2}$-axis runs between the atoms $\mathrm{Ca}$ and $\mathrm{O}$. The coordinated THF molecule resides in the usual position at the open edge of the two $\mathrm{pdl}^{*}$ ligands. In contrast, 2 exhibits crystallographically imposed $C_{2}$ symmetry with two coordinated THF ligands, which are located at the rear of the $\mathrm{pdl}^{*}$ systems. Therefore the pentadienyls adopt different orientations with respect to each other (Chart 3). In the Ca compound 1 the arrangement of the ligands is better described by a syn-eclipsed conformation $\left(\chi=28.4^{\circ}\right)$, whereas for the Sr system 2 a gauche- 1 arrangement is realized $\left(\chi=50.0^{\circ}\right)$. Compared to other enantiomerically pure open metallocenes derived from the $\mathrm{pdl}^{*}$ framework or related ligands, these values are the smallest observed so far..$^{35-38,40}$

Because of the predominantly ionic bonding in these complexes, the various arrangements are probably enforced by the minimization of inter-ligand repulsions. The $\mathrm{C}-\mathrm{C}$ bond distances feature a distinct short-long-long-short pattern, whereby the shortest $\mathrm{M}-\mathrm{C}$ bond distance is formed to the central carbon atom (C3-position) of the pdl* ligand, and they become progressively longer from $\mathrm{C} 2 / \mathrm{C} 4$ to $\mathrm{C} 1 / \mathrm{C} 5$. However, the $\mathrm{M}-\mathrm{C} 4 / \mathrm{C} 5$ bond distances are significantly longer than the corresponding $\mathrm{M}-\mathrm{C} 1 / \mathrm{C} 2$ distances, which is presumably a consequence of the more sterically demanding bicyclic framework. Furthermore, the average M-C distances are $2.727 \pm 0.085 \AA$ and $2.917 \pm 0.037 \AA$ for 1 and 2, respectively. This correlates well with the difference between the ionic radii of heptacoordinate $\mathrm{Ca}^{2+}(1.06 \AA)$ and octacoordinate $\mathrm{Sr}^{2+}(1.26 \AA) .{ }^{59}$ Another notable aspect is the comparison of $\mathrm{pdl}^{*}$ to the sterically more encumbered $\mathrm{pdl}$ ligand ( $\left.\mathrm{pdl} \mathrm{l}^{\prime}=2,4-\left(\mathrm{Me}_{3} \mathrm{C}\right)_{2} \mathrm{C}_{5} \mathrm{H}_{5}\right)$, for which only mono THF-adducts $\left[\left(\eta^{5}-\text { pdl }^{\prime}\right)_{2} \mathrm{M}(\right.$ thf $\left.)\right](\mathrm{M}=\mathrm{Ca}$ and $\mathrm{Sr})$ are isolated. ${ }^{37}$

\section{Polymerization of rac-lactide}

With complexes $\mathbf{1}$ and $\mathbf{2}$ in hand we set out to investigate their reactivity in the heterotactic ring opening polymerization (ROP) of rac-lactide ( $r a c$-LA) (Chart 4).

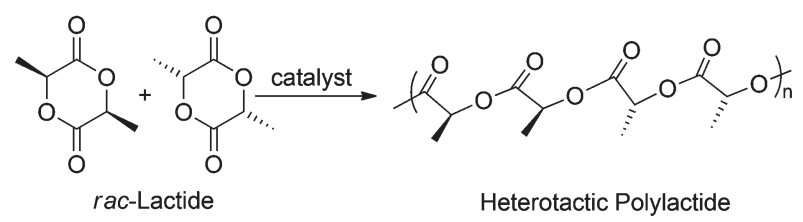

Chart 4 Heterotactic polylactide formation. 
Table 3 Polymerization of rac-lactide catalyzed by open metallocenes 1 and $2^{a}$

\begin{tabular}{llllllll}
\hline Entry & Cat. & Solvent & \multicolumn{1}{c}{$\begin{array}{l}\text { Conv. } \\
(\%)\end{array}$} & $\begin{array}{l}M_{\mathrm{n}, \exp }{ }^{b} \\
\left(\mathrm{~kg} \mathrm{~mol}^{-1}\right)\end{array}$ & $\begin{array}{l}M_{\mathrm{n}, \mathrm{calc}^{c}} \\
\left(\mathrm{~kg} \mathrm{~mol}^{-1}\right)\end{array}$ & $M_{\mathrm{w}} / M_{\mathrm{n}}{ }^{b}$ & $\begin{array}{l}P_{\mathrm{r}}{ }^{d} \\
(\%)\end{array}$ \\
\hline 1 & $\mathbf{1}$ & Toluene & 98 & 14.2 & 14.1 & 1.29 & 0.62 \\
2 & 2 & Toluene & 100 & 14.6 & 14.4 & 1.31 & 0.60 \\
3 & $\mathbf{1}$ & THF & 97 & 14.1 & 14.0 & 1.30 & 0.63 \\
4 & $\mathbf{2}$ & THF & 98 & 14.3 & 14.1 & 1.29 & 0.61
\end{tabular}

${ }^{a}$ Conditions: [precat.]/LA $(\mathrm{mol} / \mathrm{mol})=1 / 100$; polymerization time, $12 \mathrm{~h}$; solvent, $5 \mathrm{~mL}$; [LA $]=0.5 \mathrm{~mol} \mathrm{~L}^{-1}$; temperature, $50{ }^{\circ} \mathrm{C} .{ }^{b}$ Measured by GPC (using polystyrene standards in THF). ${ }^{c}$ Calculated by ([LA]/ [precat.] $) \times 144 \times X\left(X=\right.$ conv.). ${ }^{d} P_{\mathrm{r}}$ is the probability of forming an $r$ dyad by insertion and is determined from the methine region of the homonuclear decoupled ${ }^{1} \mathrm{H}$ NMR spectrum in $\mathrm{CDCl}_{3}$ at $25^{\circ} \mathrm{C}$.

Complete conversion of 100 equiv. of lactide ([rac-LA $]=$ $0.5 \mathrm{~mol} \mathrm{~L}^{-1}$ ) can be achieved within $12 \mathrm{~h}$ at $50{ }^{\circ} \mathrm{C}$. No activators need to be added and a switch in solvent polarity (toluene $v s$. THF) has no influence on the reaction rate or polymer structure. This suggests that THF is not competing for monomer at the active site of the catalyst. The ROP of rac-lactide catalyzed by 1 and 2 proceeds slower than for allyl rare earth complexes such as $\left[\left(\eta^{3} \text {-allyl }\right)_{3} \mathrm{M}(\text { dioxane })\right]_{x}(\mathrm{M}=\mathrm{Y}$, $\mathrm{La}, \mathrm{Sm})$ or $\left[(\right.$ nacnac $\left.\left.) \mathrm{M}\left(\eta^{3} \text {-allyl }\right)_{3}\right)\right](\mathrm{M}=\mathrm{La}, \mathrm{Y}, \mathrm{Sm}, \mathrm{Nd}$; nacnac $=$ $\left.\mathrm{HC}\left(\mathrm{MeCNC}_{6} \mathrm{H}_{3} \mathrm{iPr}_{2}-2,6\right)_{2}\right),{ }^{60}$ but whereas in the latter cases atactic polymers were isolated, the open metallocenes $\mathbf{1}$ and $\mathbf{2}$ furnish heterotactic-enriched polylactides with $P_{\mathrm{r}}$ of 0.61-0.63. In addition the experimental $M_{\mathrm{n}}$ values $\left(M_{\mathrm{n}, \exp }\right)$

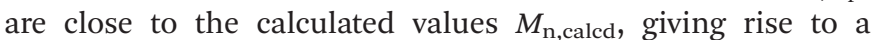
narrow polydispersity $\left(M_{\mathrm{w}} / M_{\mathrm{n}}=1.29-1.31\right.$; Table 3$)$. It should also be noted that the selectivities and activities of $\mathbf{1}$ and 2 are virtually identical, suggesting that the difference in ionic radii has no influence on the polymerization process. Group 2 complexes bearing either alkoxido, amido or $\mathrm{BH}_{4}$ groups usually initiate faster than complexes $\mathbf{1}$ and $\mathbf{2}$. Very reactive complexes in this context are $\left[\left\{\mathrm{HB}(3-t \mathrm{Bupz})_{3}\right\} \mathrm{CaN}\right.$ $\left.\left(\mathrm{SiMe}_{3}\right)_{2}\right]$ or $\left[\left\{\mathrm{HB}(3-t \mathrm{Bupz})_{3}\right\} \mathrm{Ca}\left(\mathrm{O}-2,6{ }_{-}{ }_{\mathrm{i}} \mathrm{Pr}_{2} \mathrm{C}_{6} \mathrm{H}_{3}\right)\right]$ that polymerizes rac-lactide rapidly at ambient temperature with up to $>90 \%$ heterolactic polylactide, but significantly broader polydispersities $M_{\mathrm{w}} / M_{\mathrm{n}}=1.6-1.7 .{ }^{61}$ Other examples also include $\left[(\right.$ nacnac $\left.) \mathrm{M}\left(\mathrm{BH}_{4}\right)(\text { thf })_{2}\right](\mathrm{M}=\mathrm{Ca}$ and $\mathrm{Sr})$ for which only atactic polymers were obtained and the $M_{\mathrm{w}} / M_{\mathrm{n}}$ increase significantly as a function of conversion approaching values of $1.7-1.8 .^{62}$ However, polydispersities in the range of 1.4 to 1.8 indicate side reactions such as transesterfications. ${ }^{62}$

A more detailed analysis was then undertaken for the Ca catalyst 1 to show that it acts as a single-site catalyst performing a controlled polymerization of rac-lactide. First order kinetics with respect to rac-LA concentration was established (Fig. 4) and the $M_{\mathrm{n}, \exp }$ values increase linearly with the monomer conversion, whereas the $M_{\mathrm{w}} / M_{\mathrm{n}}$ values remain in the range of 1.28-1.31 independent of conversion suggesting that no side reactions occur (Fig. 5).

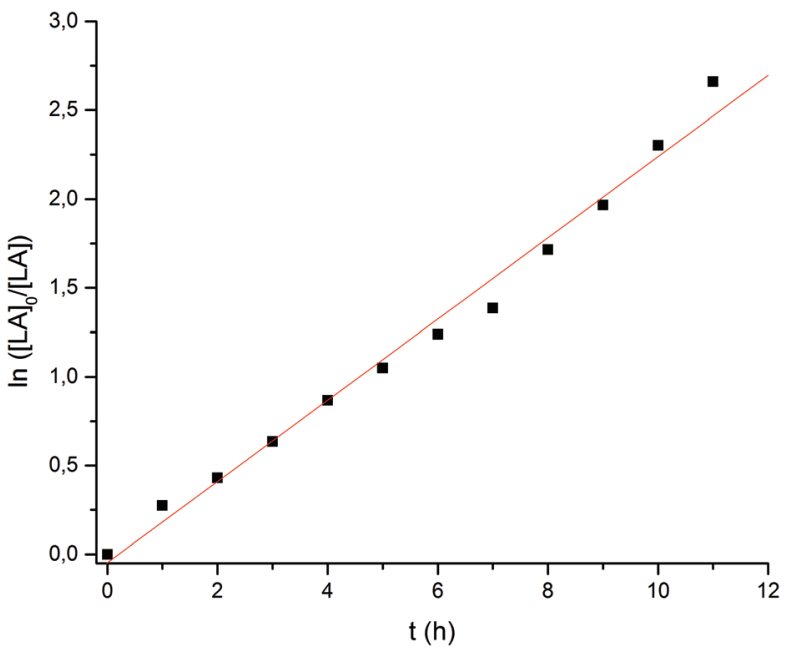

Fig. $4 \mathrm{Ln}\left([\mathrm{LA}]_{0} /[\mathrm{LA}]\right)$ vs. time plot for the ROP of rac-LA initiated by $\mathrm{Ca}$ complex. Conditions: precat./LA $(\mathrm{mol} / \mathrm{mol})=1 / 100,[L A]_{0}=0.5 \mathrm{~mol} \mathrm{~L}-1$, solvent $=\mathrm{THF}, T=50^{\circ} \mathrm{C} . k_{\mathrm{obs}}=0.189 \mathrm{~h}^{-1}$ (or $5.25 \times 10^{-5} \mathrm{~s}^{-1}$ ).

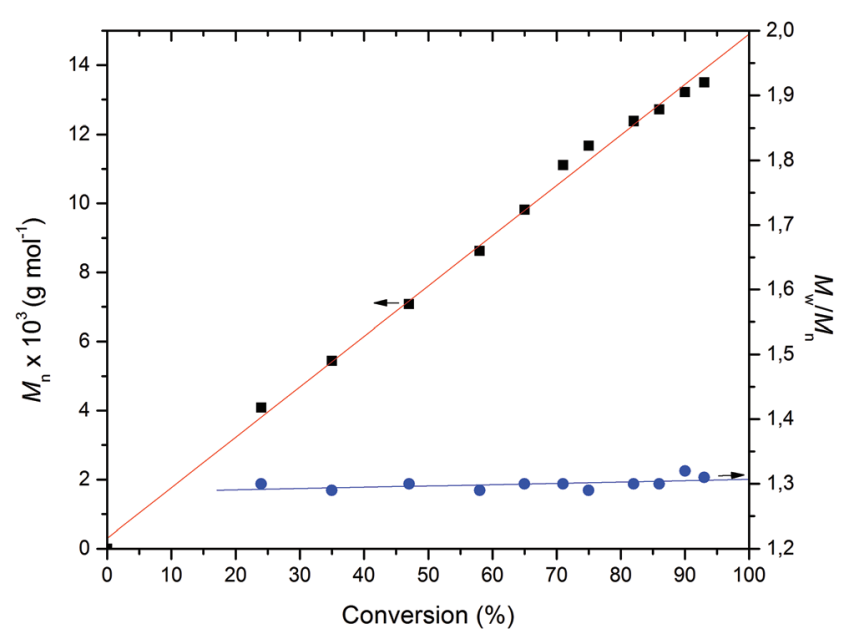

Fig. $5 M_{n}$ and $M_{w} / M_{n}$ vs. conversion plots for the ROP of rac-LA initiated by Ca complex. Conditions: precat./LA $(\mathrm{mol} / \mathrm{mol})=1 / 100$, $[\mathrm{LA}]_{0}$ $=0.5 \mathrm{~mol} \mathrm{~L}-1$, solvent $=\mathrm{THF}, T=50^{\circ} \mathrm{C}$.

\section{Conclusion}

The first enenatiomerically pure open metallocenes of group 2 metals were successfully isolated and fully characterized. In the $\mathrm{Ca}$ and $\mathrm{Sr}$ complexes $\mathbf{1}$ and $\mathbf{2}$, the pentadienyl ligands adopt an $\eta^{5}-\mathrm{U}$ conformation in solution and in the solid state. It was further established that the $\mathrm{pdl}^{*}$ ligands coordinate exclusively from the sterically less demanding site of the bicycle (that is, syn to the $\mathrm{CH}_{2}$-bridge). However, in contrast to the sterically more demanding pdl' system, the number of coordinated THF ligands varies between $\mathrm{Ca}$ and $\mathrm{Sr}$, suggesting that $\mathrm{pdl}^{*}$ is slightly less sterically demanding than the corresponding pdl' derivative. Complexes $\mathbf{1}$ and $\mathbf{2}$ are active catalysts 
in the ROP of rac-lactide without the necessity to add any activators. During the polymerization process $M_{\mathrm{n}, \exp }$ increases linearly with conversion, yielding heterotactic-enriched polymers with narrow polydispersities (PDI $=1.29-1.31)$. Further investigations regarding catalytic applications of pentadienyl complexes are ongoing and will be reported in due course.

\section{Experimental}

\section{General considerations}

Synthetic and spectroscopic manipulations were performed under an atmosphere of purified nitrogen, either in a Schlenk apparatus or in a glovebox. Solvents were dried and deoxygenated either by distillation under a nitrogen atmosphere from sodium benzophenone ketyl (THF) or by an MBraun $\mathrm{GmbH}$ solvent purification system (all other solvents). NMR data were recorded on a Bruker DPX 200 spectrometer at ambient temperature unless stated otherwise. The chemical shifts were referenced to the residual solvent signal $\left(\delta_{\mathrm{H}} 7.16\right.$ for benzene, 7.26 for chloroform, $3.58 \mathrm{ppm}$ for $\alpha-H$ of THF) for the ${ }^{1} \mathrm{H}$ NMR spectra and the solvent signal $\left(\delta_{\mathrm{C}} 128.06\right.$ for benzene, 67.21 ppm for $\alpha-C$ of THF) for the ${ }^{13} \mathrm{C}\left\{{ }^{1} \mathrm{H}\right\}$ NMR spectra. Elemental analyses were performed by combustion and gas chromatographic analysis with an Elementar varioMICRO instrument. Despite several attempts, the carbon values for complexes 1-2 were lower than expected because of incomplete combustion and the extreme sensitivity of these compounds to air and moisture. Nevertheless, low carbon values were uncommon for alkylcyclopentadienyl complexes of the heavy alkalineearth metals, e.g. ref. 63 and 64 and literature cited therein, and ref. 65. Racemic lactide (rac-LA) was recrystallized twice from dry toluene and then sublimed under vacuum prior to use.

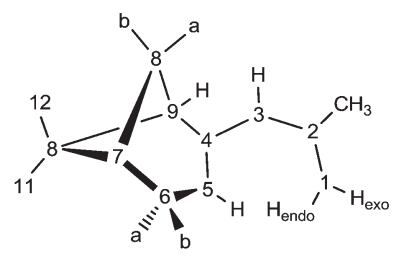

\section{Synthesis}

Preparation of $\left[\left(\eta^{5}-\mathbf{p d l}\right)_{2} \mathbf{C a}(\right.$ thf $\left.)\right]$. A suspension of $\mathrm{CaI}_{2}$ (206 mg, $0.70 \mathrm{mmol})$ in THF $(10 \mathrm{~mL})$ was stirred for $10 \mathrm{~min}$. To this saturated solution a solution of $\mathrm{K}\left(\mathrm{pdl}^{*}\right)$ (300 mg, $1.40 \mathrm{mmol})$ in THF $(10 \mathrm{~mL})$ was added. The mixture was stirred for $30 \mathrm{~min}$ at ambient temperature. The red to brown solution was separated from a pale yellow precipitate by filtration and the solvent was reduced under dynamic vacuum to $1 \mathrm{~mL}$. Orange to yellow single crystals grew from a concentrated hexane solution at $-30{ }^{\circ} \mathrm{C}$ (103 mg, $\left.0.22 \mathrm{mmol}, 32 \%\right)$. Anal. Calcd for $\mathrm{C}_{30} \mathrm{H}_{46} \mathrm{CaO}$ : C, 77.86; H, 10.02. Found: C, 77.20; H, 10.39. ${ }^{1} \mathrm{H}$ NMR $(400 \mathrm{MHz}$, ambient temperature, $\mathrm{C}_{6} \mathrm{D}_{6}$ ): $\delta=4.29$ (s, $\left.2 \mathrm{H}, 5\right), 4.12$ ("s", $\left.2 \mathrm{H}, 3\right), 3.77$ (s, $2 \mathrm{H}, 1$-exo), 3.48 (s, 2 H, 1-endo), 3.41-3.34 (m, 4 H, THF), 2.62-2.53 (m, 4,
$\mathrm{H}, 6 \mathrm{~b}$ and 8b), 2.49-2.40 (m, $2 \mathrm{H}, 6 \mathrm{a}), 2.23$ ("d", $4 \mathrm{H}, J=$ $5.27 \mathrm{~Hz}, 7$ and 9), 2.13 (s, $6 \mathrm{H}, 13), 1.59$ (d, $2 \mathrm{H}, J=9.03 \mathrm{~Hz}$, 8a), 1.36 (s, $6 \mathrm{H}, 12$ ), 1.22-1.18 (m, 4 H, THF), 1.17 (s, $6 \mathrm{H}, 11)$ ppm. ${ }^{13} \mathrm{C}$ NMR (100 MHz, ambient temperature, $\left.\mathrm{C}_{6} \mathrm{D}_{6}\right): \delta=$ 154.0 (C, 4), 149.6 (C, 2), $89.2(\mathrm{CH}, 5), 89.1(\mathrm{CH}, 3), 77.1\left(\mathrm{CH}_{2}\right.$, 1), $69.1\left(\mathrm{CH}_{2}, \mathrm{THF}\right), 52.8(\mathrm{CH}, 9), 41.6(\mathrm{CH}, 7), 38.8$ (C, 10), $33.4\left(\mathrm{CH}_{2}, 8\right), 32.4\left(\mathrm{CH}_{2}, 6\right), 28.8\left(\mathrm{CH}_{3}, 13\right), 26.8\left(\mathrm{CH}_{3}, 12\right), 25.2$ $\left(\mathrm{CH}_{2}, \mathrm{THF}\right), 21.6\left(\mathrm{CH}_{3}, 11\right) \mathrm{ppm}$.

Preparation of $\left[\left(\eta^{5}-\mathbf{p d l}\right)_{2} \operatorname{Sr}(\text { thf })_{2}\right]$. To a suspension of $\mathrm{SrI}_{2}$ (239 $\mathrm{mg}, 0.70 \mathrm{mmol})$ in THF $(10 \mathrm{~mL})$ was added a solution of $\mathrm{K}\left(\mathrm{pdl}^{*}\right)$ (300 mg, $\left.1.40 \mathrm{mmol}\right)$ in THF $(10 \mathrm{~mL})$. The brown to red suspension was stirred for $30 \mathrm{~min}$ at room temperature. Afterwards the solution was separated from a pale yellow precipitate by filtration and the solvent was reduced under dynamic vacuum to $1 \mathrm{~mL}$. Single crystals grew from a concentrated hexane solution at $-30{ }^{\circ} \mathrm{C}$ (134 mg, $\left.0.13 \mathrm{mmol}, 33 \%\right)$. Anal. Calcd for $\mathrm{C}_{34} \mathrm{H}_{54} \mathrm{SrO}_{2}$ : C, 70.12; H, 9.35. Found: C, 69.26; $\mathrm{H}$, 9.58. ${ }^{1} \mathrm{H}$ NMR (400 MHz, ambient temperature, $\left.\mathrm{C}_{6} \mathrm{D}_{6}\right): \delta=$ 4.52 ("bs", $1 \mathrm{H}, 5$ ), 3.98-3.83 (m, $2 \mathrm{H}, 1$-exo and 3), 3.78 ("bs", $1 \mathrm{H}$, 1-endo), 3.52-3.45 (m, $8 \mathrm{H}, \mathrm{THF}), 2.88-2.64$ (m, $2 \mathrm{H}, 6)$, 2.53-2.43 (m, $1 \mathrm{H}, 8 \mathrm{~b}), 2.28-2.21$ (m, $1 \mathrm{H}, 7), 2.17-2.09$ (m, $1 \mathrm{H}, 9), 2.02$ (s, $3 \mathrm{H}, 13$ ), 1.52 (brd, $1 \mathrm{H}, J=8.53 \mathrm{~Hz}, 8 \mathrm{a}), 1.38$ (brs, $3 \mathrm{H}, 12$ ), 1.37-1.31 (m, $8 \mathrm{H}$, thf),1.22 (brs, $3 \mathrm{H}, 11$ ) ppm. ${ }^{13} \mathrm{C}$ NMR (100 MHz, ambient temperature, $\left.\mathrm{C}_{6} \mathrm{D}_{6}\right): \delta=152.8$ (C, 4), $147.2(\mathrm{C}, 2), 89.2(\mathrm{CH}, 5), 86.6(\mathrm{CH}, 3), 78.9\left(\mathrm{CH}_{2}, 1\right)$, $68.6\left(\mathrm{CH}_{2}, \mathrm{THF}\right), 52.9$ (CH, 9), 41.8 (CH, 7), 39.3 (C, 10), 32.3 $\left(\mathrm{CH}_{2}, 8\right), 32.2\left(\mathrm{CH}_{2}, 6\right), 28.6\left(\mathrm{CH}_{3}, 13\right), 26.9\left(\mathrm{CH}_{3}, 12\right), 25.5$ $\left(\mathrm{CH}_{2}, \mathrm{THF}\right), 21.6\left(\mathrm{CH}_{3}, 11\right) \mathrm{ppm}$.

\section{General procedure for the polymerization of rac-lactide}

In a glovebox, a rac-lactide (rac-LA) (0.360 g, $2.5 \mathrm{mmol})$, toluene or THF (4.0 mL), and complex (typically $0.025 \mathrm{mmol}$, in $1.0 \mathrm{~mL}$ of toluene or THF) were added sequentially into a Schlenk flask with stirring. The flask containing the reaction mixture was subsequently placed in an oil bath and stirred for $12 \mathrm{~h}$ at $50{ }^{\circ} \mathrm{C}$. The polymerization was quenched by the addition of cold acidified methanol $(20 \mathrm{~mL}, 10 \% \mathrm{HCl})$. The precipitated polylactide was collected, washed with cold methanol several times, and dried in vacuum at $50{ }^{\circ} \mathrm{C}$ overnight.

\section{Crystallographic details}

Single crystals of each compound were examined under inert oil. Data were recorded at 100(2) K on Oxford Diffraction diffractometers using monochromated MoK $\alpha$ radiation (Table 1). Absorption corrections were performed on the basis of multi-scans. The structures were refined anisotropically using the SHELXL-97 program. ${ }^{66}$ Hydrogen atoms at the 1-, 3and 5-positions of the pdl* ligands were refined freely (but for 2 with distance restraints); methyl groups were refined as idealised rigid groups allowed to rotate but not tip. Other hydrogen atoms were refined using a riding model starting from calculated positions. Absolute configurations were confirmed unambiguously by the Flack parameters. Special features and exceptions: The coordinated THF in 2 was disordered and was refined on two positions. The assignment of 
the oxygen position for the uncoordinated THF, which is disordered over a twofold axis, was not straightforward. The $U$ values are not convincing, but other permutations of $\mathrm{O}$ and $\mathrm{C}$ led to very short $\mathrm{H} \cdots \mathrm{H}$ contacts. In any case, this molecule may be more seriously disordered and its geometry should be interpreted with caution. Attempts to refine the structure in space group $P 3_{1}$ (in the hopes that the THF molecules might be ordered) were unsuccessful; the disorder remained.

\section{Acknowledgements}

This work was supported by the Deutsche Forschungsgemeinschaft (DFG) (WA 2513/2, WA 2513/6, WA 2513/7) (M.D.W.) and the National Natural Science Foundation of China (Grant No. 21472013, 21172022) (G.Z.).

\section{Notes and references}

1 C. Janiak and H. Schumann, Adv. Organomet. Chem., 1991, 33, 291-393.

2 J. Okuda, Top. Curr. Chem., 1992, 160, 97-145.

3 R. L. Halterman, Chem. Rev., 1992, 92, 965-994.

4 A. Glöckner, H. Bauer, M. Maekawa, T. Bannenberg, C. G. Daniliuc, P. G. Jones, Y. Sun, H. Sitzmann, M. Tamm and M. D. Walter, Dalton Trans., 2012, 41, 6614-6624.

5 H. Bauer, A. Glöckner, A. C. Tagne Kuate, S. Schäfer, Y. Sun, M. Freytag, M. Tamm, M. D. Walter and H. Sitzmann, Dalton Trans., 2014, 43, 15818-15828.

6 R. D. Ernst, Struct. Bonding, 1984, 57, 1-53.

7 R. D. Ernst, Acc. Chem. Res., 1985, 18, 56-62.

8 R. D. Ernst, Chem. Rev., 1988, 88, 1255-1291.

9 R. D. Ernst, Comments Inorg. Chem., 1999, 21, 285-325.

10 L. Stahl and R. D. Ernst, Adv. Organomet. Chem., 2008, 55, 137-199.

11 R. D. Ernst and T. H. Cymbaluk, Organometallics, 1982, 1, 708-713.

12 J. Sieler, A. Simon, K. Peters, R. Taube and M. Geitner, J. Organomet. Chem., 1989, 362, 297-293.

13 H. Schumann and A. Dietrich, J. Organomet. Chem., 1991, 401, C33-C36.

14 W. Q. Weng, K. Kunze, A. M. Arif and R. D. Ernst, Organometallics, 1991, 10, 3643-3647.

15 K. Kunze, A. M. Arif and R. D. Ernst, Bull. Soc. Chim. Fr., 1993, 130, 708-711.

16 M. B. Zielinski, D. K. Drummond, P. S. Iyer, J. T. Leman and W. J. Evans, Organometallics, 1995, 14, 3724-3731.

17 J. Wang, C. Zheng, G. Canseco-Melchor, D. J. Hilby, J. A. Maguire and N. S. Hosmane, Organometallics, 2007, 26, 577-585.

18 M. R. Kunze, J. Sieler and R. Taube, Z. Anorg. Allg. Chem., 2008, 634, 1045-1050.

19 M. R. Kunze, D. Steinborn, K. Merzeriler, C. Wagner, J. Sieler and R. Taube, Z. Anorg. Allg. Chem., 2007, 633, 1451-1463.
20 M. R. Kunze and R. Taube, Z. Anorg. Allg. Chem., 2010, 636, 2454-2461.

21 B. M. Day, N. F. Chilton and R. A. Layfield, Dalton Trans., 2015, 44, 7109-7113.

22 T. H. Cymbaluk, J. Z. Liu and R. D. Ernst, J. Organomet. Chem., 1983, 255, 311-315.

23 D. Baudry, E. Bulot and M. Ephritikhine, J. Chem. Soc., Chem. Commun., 1988, 1369-1370.

24 D. Baudry, E. Bulot and M. Ephritikhine, J. Chem. Soc., Chem. Commun., 1989, 1316-1317.

25 D. Baudry, E. Bulot, P. Charpin, M. Ephritikhine, M. Lance, M. Nierlich and J. Vigner, J. Organomet. Chem., 1989, 371, 163-174.

26 S. A. Solomon, F. M. Bickelhaupt, R. A. Layfield, M. Nilsson, J. Poater and M. Sola, Chem. Commun., 2011, 47, 6162-6164.

27 B. M. Day, J. Clayden and R. A. Layfield, Organometallics, 2013, 32, 4448-4451.

28 B. M. Day, J. J. W. McDouall, J. Clayden and R. A. Layfield, Organometallics, 2015, 34, 2348-2355.

29 J. S. Overby and T. P. Hanusa, Angew. Chem., Int. Ed. Engl., 1994, 33, 2191-2193.

30 J. Klein and S. Glily, Tetrahedron, 1971, 27, 3477-3494.

31 H. Yasuda, Y. Ohnuma, A. Nakamura, Y. Kai, N. Yasuoka and N. Kasai, Bull. Chem. Soc. Jpn., 1980, 53, 1101-1111.

32 H. Yasuda, T. Nishi, K. Lee and A. Nakamura, Organometallics, 1983, 2, 21-27.

33 H. Yasuda and A. Nakamura, J. Organomet. Chem., 1985, 285, 15-29.

34 H. Yasuda, T. Nishi, S. Miyanaga and A. Nakamura, Organometallics, 1985, 4, 359-367.

35 A. C. Fecker, A. Glöckner, C. G. Daniliuc, M. Freytag, P. G. Jones and M. D. Walter, Organometallics, 2013, 32, 874-884.

36 A. C. Fecker, B.-F. Craciun, M. Freytag, P. G. Jones and M. D. Walter, Organometallics, 2014, 33, 3792-3803.

37 M. Reiners, A. C. Fecker, M. Freytag, P. G. Jones and M. D. Walter, Dalton Trans., 2014, 43, 6614-6617.

38 A. C. Fecker, B.-F. Craciun, P. Schweyen, M. Freytag, P. G. Jones and M. D. Walter, Organometallics, 2015, 34, 146-158.

39 J. W. Freeman, D. R. Wilson, R. D. Ernst, P. D. Smith, D. D. Klendworth and M. P. McDaniel, J. Polym. Sci., Part A: Polym. Chem., 1987, 25, 2063-2075.

40 M. Reiners, D. Baabe, P. Schweyen, M. Freytag, P. G. Jones and M. D. Walter, Inorg. Chim. Acta, 2014, 422, 167-180.

41 S. Harder, Chem. Rev., 2010, 110, 3852-3876.

42 E. Chiellini and R. Solaro, Adv. Mater., 1996, 8, 305-313.

43 K. E. Uhrich, S. M. Cannizzaro, R. S. Langer and K. M. Shakesheff, Chem. Rev., 1999, 99, 3181-3198.

44 R. E. Drumright, P. R. Gruber and D. E. Henton, Adv. Mater., 2000, 12, 1841-1846.

45 R. H. Platel, L. M. Hodgson and C. K. Williams, Polym. Rev., 2008, 48, 11-63.

46 M. J. Stanford and A. P. Dove, Chem. Soc. Rev., 2010, 39, 486-494. 
47 Y. Ikada, K. Jamshidi, H. Tsuji and S. H. Hyon, Macromolecules, 1987, 20, 904-906.

48 H. Tsuji and Y. Ikada, Polymer, 1999, 40, 66996708.

49 M. S. Reeve, S. P. McCarthy, M. J. Downey and R. A. Gross, Macromolecules, 1994, 27, 825-831.

50 J.-R. Sarasua, R. E. Prud'homme, M. Wisniewski, A. Le Borgne and N. Spassky, Macromolecules, 1998, 31, 38953905.

51 N. Nomura, J. Hasegawa and R. Ishii, Macromolecules, 2009, 42, 4907-4909.

52 O. Dechy-Cabaret, B. Martin-Vaca and D. Bourissou, Chem. Rev., 2004, 104, 6147-6176.

53 N. E. Kamber, W. Jeong, R. M. Waymouth, R. C. Pratt, B. G. G. Lohmeijer and J. L. Hedrick, Chem. Rev., 2007, 107, 5813-5840.

54 C. A. Wheaton, P. G. Hayes and B. J. Ireland, Dalton Trans., 2009, 4832-4846.

55 A. K. Sutar, T. Maharana, S. Dutta, C.-T. Chen and C.-C. Lin, Chem. Soc. Rev., 2010, 39, 1724-1746.

56 C. A. Wheaton and P. G. Hayes, Comments Inorg. Chem., 2011, 32, 127-162.
57 A. Sauer, A. Kapelski, C. Fliedel, S. Dagorne, M. Kol and J. Okuda, Dalton Trans., 2013, 42, 9007-9023.

58 N. Zhao, G. Hou, X. Deng, G. Zi and M. D. Walter, Dalton Trans., 2014, 43, 8261-8272.

59 R. Shannon, Acta Crystallogr., Sect. A: Cryst. Phys., Diffr., Theor. Gen. Cryst., 1976, 32, 751-767.

60 L. F. Sánchez-Barba, D. L. Hughes, S. M. Humphrey and M. Bochmann, Organometallics, 2005, 24, 3792-3799.

61 M. H. Chisholm, J. Gallucci and K. Phomphrai, Chem. Commun., 2003, 48-49.

62 R. A. Collins, J. Unruangsri and P. Mountford, Dalton Trans., 2013, 42, 759-769.

63 M. J. Harvey and T. P. Hanusa, Organometallics, 2000, 19, 1556.

64 M. J. McCormick, S. C. Sockwell, T. P. Hanusa and J. C. Huffman, J. Am. Chem. Soc., 1992, 114, 3393.

65 M. J. Harvey, T. P. Hanusa and V. G. Young Jr., J. Organomet. Chem., 2001, 626, 43.

66 (a) G. M. Sheldrick, SHELXL-97, Program for the Refinement of Crystal Structure from Diffraction Data, University of Göttingen, Göttingen, 1997; (b) G. M. Sheldrick, Acta Crystallogr., Sect. A: Fundam. Crystallogr., 2008, 64, 112-122. 